\title{
'WAR IS NOT ALWAYS VIOLENT AND VIOLENCE IS NOT ALWAYS WAR.' - AN ANECDOTE ON HOW LANGUAGE AND ULTIMATELY THE LAW IS USED TO PERPETUATE EPISTEMIC VIOLENCE IN SOUTH AFRICA
}

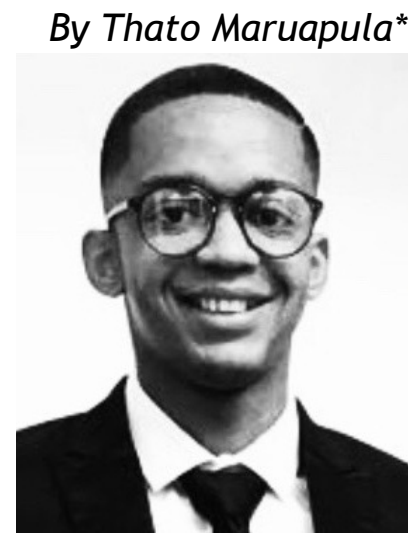

\section{Introduction}

The focus of this paper will be how linguicide is used as a mechanism to perpetuate epistemic violence in South Africa and how epistemic diversity is needed in order for those who find themselves 'below the law' to ascertain access to justice. Firstly, I will define the concepts 'linguicide' and 'epistemic violence.' Secondly, I will offer a critique on how the English language is not neutral but rather a socioeconomic tool that shapes power relations within society. Thirdly, I will introduce the critical theories of Black Consciousness and Marxism to show how the law is complicit in perpetuating racial and

* Third year LLB student, University of Pretoria. This article discusses how linguicide perpetuates epistemic violence and the need for epistemic diversity therein. I would like to thank Dr Joel Modiri for his critical engagement and advice. My colleagues Tshepo Twala, Nelsie Siboza, Keneilwe Molaudi and Vaughn Rajah for their feedback and patience while I was writing this article. All errors and shortcomings are undoubtedly my own. Pula! 
class inequalities in South Africa. I will then conclude with how access to justice can become a reality through the paradigm of decolonisation ('of the mind') as understood by various African authors and provide recommendations of an imagined alternative.

\section{Understanding linguicide and epistemic violence}

My main argument revolves around the idea that language and indeed the law, is not neutral but rather mechanisms to perpetuate imperialism and oppression in the 21st century. It is thus important to define concepts that form the nucleus of my argument, namely linguicide and epistemic violence. The term 'linguicide' refers to the death of a language from either natural or political causes. ${ }^{1}$ Since language is a social practice that determines power relations and shapes subjectivity, it cannot be said that language is a politically neutral medium of communication. ${ }^{2}$ It can therefore be said that a particular language and the culture it carries are the most crucial parts of that naming system by which Europe subjected the colonised to its memory. ${ }^{3}$ Ngugi argues that the more 'educated the colonial subjects are in the culture of the coloniser, the more severe the subjugation." 4 The consequence of such 'education' is the oppressor's culture being the death of indigenous languages, used in this context interchangeably with culture, by political causes.

On the other hand, the abstract concept of epistemic violence refers to the 'suppression, rejection and in some cases literal destruction (wiping out) of indigenous knowledge. ${ }^{5}$ I thus contend that the term epistemic violence is a theoretical umbrella that is broad enough to encapsulate linguicide. As a result, epistemic violence and its various manifestations suppress indigenous knowledge by inducing a 'historical amnesia' on the colonised by mutilating the memory of the colonised and where it failed, by remembering it with the coloniser's memory. ${ }^{6}$ Throughout the course of this paper, the reference to linguicide should be understood against the backdrop of epistemic violence.

1 http://www.yourdictionary.com/linguicide (accessed 23 September 2018).

2 A Parmegiani 'Language, power and transformation in South Africa' Stellenbosch Papers on Linguistics (2008) 74.

3 W Ngugi Something torn and new: An African Renaissance (2009) 114.

$4 \quad$ Ngugi (n 3) 114.

$5 \quad \mathrm{~K}$ Van Marle 'The complicity of language, knowledge and justice' (2017) 49(1) Acta Academia at 104.

$6 \quad$ Ngugi (n 3) 108. 


\section{Oppression in a post-democratic era: A proudly South African anecdote}

Having defined what linguicide entails and its interplay with the broad notion of epistemic violence, I will now demonstrate its effects on the South African society. The Constitution is the 'supreme law' of the land. ${ }^{7}$ Furthermore, as the somewhat 'tourist attraction' of our new legal system, the Constitution starts by unequivocally stating that the people 'recognise the injustices of the past. ${ }^{8}$ One would assume that these 'injustices' are not limited to, colonisation and then later apartheid that still continues to this day, albeit in a different form. This new manifestation of apartheid is oppression based on language rather than the colour of your skin. Of all the 11 languages recognised by the Constitution, English is by far the most dominant in all spheres of the South African society, even though the vast majority of South Africans do not consider English as their mother tongue (including white Afrikaans speakers). Furthermore, English is often seen as mandatory for professional employment, political participation and even academic success. ${ }^{9}$

The dawn of 'democracy' in 1994 signalled an end in overt racial discrimination but the dominance of the English (as a product of colonialism) remained hegemonic in key areas of our society as an important mechanism for '(re)producing social stratification'10 and ensured that South Africa has transitioned from a racist to a 'linguistic'11 socio-economic system. ${ }^{12}$

Parmegiani identifies three metaphors that show how the use of English as a medium of instruction can serve as an obstacle to progressive socio-economic transformation. ${ }^{13}$ Firstly, English is compared to a 'poacher' that is responsible for linguicide genocide: because of its hegemonic powers in key areas, other languages (in particular indigenous languages) are pushed to the periphery of society and moved closer to 'extinction.'14 Secondly, English is described as a 'gatekeeper' that ensures that society remains 'highly stratified: with a lack of proficiency in English used as a subtle mechanism to exclude people from education and employment'

7 The Constitution of the Republic of South Africa, 1996 (the Constitution, 1996) sec 2 .

8 The Constitution, 1996 (n 7) preamble.

9 Parmegiani (n 2) 75.

10 Parmegiani (n 2) 75.

11 Parmegiani (n 2) 75.

12 Parmegiani (n 2) 75.

13 Parmegiani (n 2) 79.

14 Parmegiani (n 2) 79 
rather than the colour of their skin, which was the hallmark of apartheid. ${ }^{15}$ Lastly, English is described as 'a coloniser of the mind:' the learning and acquisition of English results in the inculcation of Euro-centric views that instil a sense of psychological inferiority of the colonised subject. ${ }^{16}$ This metaphor that English is a "coloniser of the mind' is discussed later in this paper.

\section{Black Consciousness and the Marxist theory as critical paradigms to show how the law is complicit in perpetuating racial and class inequalities}

\subsection{Black Consciousness}

'Being black is not a matter of pigmentation - being black is a reflection of a mental attitude., 17

Black Consciousness (BC) was not a political party formed in the 1970s but rather a philosophy about 'an attitude of mind, a way of life' that would liberate black aspirations and Black people. ${ }^{18}$ In essence, BC advocated for the need of black people to rally together against the root cause of their oppression - their black skin and to demonstrate the lie that black is an 'aberration from the normal' which is of course is white. ${ }^{19}$ Biko traces the origins of discrimination against black people to the days of colonisation which resulted in 'nothing more sinister than cultural or geographical fusion at best or language bastardisation at worst. ${ }^{20}$ Biko further contends that white people derive security and pleasure from exploiting the minds and bodies of unsuspecting black masses, hence why in no point in history has white people exploited other white people on a scale remotely close to how black people were exploited in South Africa and the African continent. $^{21}$

Apartheid served as the global blueprint to legitimise racism and made it a sin to be black in South Africa, even though the overwhelming majority of the population was, and continues to still be, black. Because being black was considered as some form of taboo, even the so called 'poor whites' during apartheid distanced themselves from black people and showed a 'reactionary attitude,' even when the Marxist theory called upon them to join black people

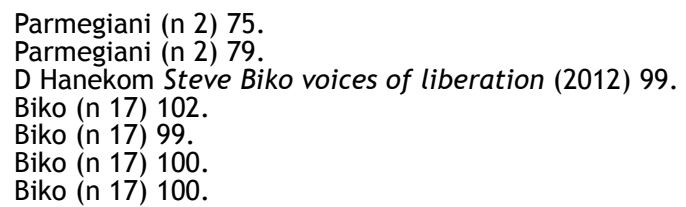


in their quest for economic emancipation. ${ }^{22}$ Biko uses the Hegelian theory of dialectic materialism, with the thesis being white racism and the only valid antithesis being black solidarity which can serve to counterbalance white racism in South Africa. ${ }^{23}$ During apartheid South Africa was characterised by overt racist laws designed to humiliate black people and now, since section 9(3) of the Constitution $^{24}$ has outlawed discrimination based on race, racism now rears its ugly head through the dominance of English as the de facto medium of instruction in all spheres of society.

\subsection{Marxism}

'For Marxists, there is nothing mysterious about the state: it is a weapon of the ruling class to be used in the class struggle. 25

It is often said that modern constitutions are a product of revolution, counterrevolution, compromise or even debate. ${ }^{26}$ Accordingly, Marxist scholars view constitutional laws as 'a set of rules that are required to guarantee the independence of this [bourgeoisie] state from one individual or group of capitalists and to guarantee loyalty to the capitalist system as a whole.'27 If we closely examine today's society, the state can be seen as the most 'refined and perfected tool' of the ruling class as it is made up of countless capitalist interests. ${ }^{28}$ For example, the notorious 'revolving door' between big business and the government ensures that civil servants and government ministers slide easily between government regulators and the very companies that they are supposed to be regulating. ${ }^{29}$ Billionaire mining-mogul turned state president, Cyril Ramaphosa is all but one example of the beneficiaries of this revolving door.

Marx uses the metaphor of a 'base' and 'superstructure' to describe society, which he refers to as the totality of social relations by which humans (re)produce their social existence. ${ }^{30}$ Biko argues that the 'real workers' (who find themselves in the metaphorical base) are black people who are exploited by the privileged white minority. ${ }^{31}$ On the other hand, the superstructure is made up of, in Lenin's terms, the 'armed bodies of men' which are institutions such

22 Biko (n 17) 101.

23 Biko (n 17) 102

24 The Constitution, 1996.

25 https://www.marxist.com/law-and-marxism-the-state-and-the-constitution.htm (accessed 24 September 2018).

26 As above.

27 (n 25).

28 As above.

29 As above.

30 S Veitch et al Jurisprudence: themes and concepts (2012) 230. See A Nash More 'The double lives of South African Marxism' in P Vale; L Hamilton and EH Prinsloo (eds) Intellectual traditions in South Africa. Ideas, individuals and institutions (2014) 227.

31 Biko (n 17 above) 101. 
as the law, the courts, prisons, police and even the army to control the means of production and ultimately, maintain 'order.' 32 In a South African context, this description becomes quite literal when you take into consideration our history of police brutality and blatant disregard for the human rights of those in the base, even with a Constitution that promises a future that's very different to our painful past. ${ }^{33}$

The 'race versus class' debate has been a (re)occurring theoretical problem in which $B C$ developed. ${ }^{34}$ Modiri contends that this debate concerns the question of 'whether it is race or class that is the primary determinant, variable or organising principle of social and economical inequality in the South African context. ${ }^{35}$ Put differently, whether the nature of social conflict in South Africa is a national-racial struggle (between the indigenous black people and white settlers) or a class struggle between workers and the ruing economic class. ${ }^{36}$ To Biko, the idea of class being more important than race in the South African context amounts to something he described as 'twisted logic' as although the capitalist system cannot be ignored (taking into account its highly racialised nature), there are aspects of black subjugation that cannot be reduced to the economic.

\section{Access to justice through the paradigm of decolonisation 'of the mind'}

Gramsci argues that there is a 'difference between the legal country and the real country. ${ }^{37}$ This is particularly true in South Africa as on paper, the law protects you from eviction and oppression but in reality, landlords and the police (as 'armed bodies of men') treat the poor as if they are below the law - as if the poor are somehow below the ambit of the constitution's protection. ${ }^{38}$ In many ways, poverty is criminalised and even treated 'as treason., 39 Zikode advocates for a society where everyone is equal before the law and the only way that this can become a reality, is if the law is de-commodified. ${ }^{40}$ The only way to effectively de-commodify the law, is to change the logic of law by means of a process called decolonisation.

32 (n 25).

33 Reference here is made to the 1960 Sharpeville massacre, the 1976 Soweto uprising and more recently, the Marikana massacre in 2012.

34 JM Modiri 'The jurisprudence of Steve Biko: A study in race, law and power in the "afterlife" of colonial-apartheid' unpublished PhD thesis, University of Pretoria, 2017 at 145.

35 Modiri (n 34) 145

36 As above.

37 S Zikode, 2 December 2011, 'Poor people's movements and the law' http://www. abahlali.org/node/8551 (accessed 24 September 2018).

38 Zikode (n 37).

39 As above.

40 Zikode (n 37). 
Ngugi writes that he was excited to visit the Eastern Cape when he came to South Africa as after all, it is the place where Sobukwe, Biko and Mandela and many more prominent figures of the African continent hail from. ${ }^{41}$ Ngugi contents that he encountered a landscape called 'Port Elizabeth', 'King Williams Town' and 'Stutterheim' - a clear indication of conquers writing their own history on the landscape of our resistance memory. ${ }^{42}$ Ngugi's thesis in 'Decolonising the mind' rests on the understanding that 'language is a carrier of culture' and he contends that Africa's cultural identity is threatened by a so called 'Western, imperialist cultural bomb' - that makes Africans see their past as 'one wasteland of non-achievement and makes them want to distance themselves from that wasteland., 43 Zandile points out the arguments against having English as a national language also indicates that English is holding black cultures, values and ultimately their minds captive. ${ }^{44}$ This links with the third metaphor identified by Parmegiani above, namely that the English language being the coloniser of the mind. According to Biko, the oppressor's greatest weapon is the mind of the oppressed. ${ }^{45} \mathrm{We}$ should therefore reject the notion that the English language is neutral, taking into account the manner in which it was violently imposed upon the indigenous communities in South Africa. What then is the alternative? Firstly, a reminder of where South Africa is geographically located in: Africa.

An imagined alternative to English being used as a cannon for both linguicide and epistemic violence is found in the notion of pluversity, which can facilitate a process of epistemic diversity. ${ }^{46}$ First, attention should be given to understanding what Philipson refers to as a theory of English Linguistic Imperialism which is the idea that the dominance of English is asserted and upheld by the establishment of continuous reconstruction of structural and cultural inequalities between English and other indigenous languages. ${ }^{47}$ Secondly, the Eurocentric canon, which only attributes 'truth to only the Western way of traditional knowledge' needs to be rejected. ${ }^{48}$ An imagined alternative sees Africans having pride in themselves, their cultures and their traditions (including languages). ${ }^{49}$

The University of KwaZulu-Natal seems to be taking the initiative as it has embarked on a journey some call 'ambitious' to develop

41 Ngugi (n 3) 113.

42 Ngugi (n 3) 113.

43 Parmegiani (n 2) 82.

44 Parmegiani (n 2) 82.

45 S Biko Black consciousness in South Africa 1977 in M Arnold (ed) xix.

46 AJ Mbembe 'Decolonizing the university: New directions' 15 (1) Arts \& Humanities in Higher Education (2016) 37.

47 Parmegiani (n 2) 84

48 Mbembe (n 46) 35.

49 Biko (n 17) 99. 
isiZulu as a language of teaching and learning which will one day have the same "institutional and academic status as English.' 50 The University of Pretoria has identified Sepedi as one of the official languages of the institution, along with English and Afrikaans. However, to date, very little has been done to facilitate the development of Sepedi as an academic language that can one day be recognised in class rooms and academic texts. Every year the Oxford English Dictionary recognises new words in the English language, yet African languages are rarely developed. ${ }^{51}$ Institutions of higher, and indeed basic, education needs to do more to promote African languages and dialogue. This will have positive ramifications on racerelations in South Africa and may even lead to people knowing what they are saying when they sing the African parts of the national anthem. The only mechanism to effect this is through the law and in particular, legislation making African languages compulsory in institutions of higher and basic education and then later, in the workplace. Once this has been implemented, we will be on the road to epistemic justice.

\section{Conclusion}

This paper has shown how the use of language has been an agent of epistemic violence in South Africa. Black Consciousness reaffirms that black people should take pride in their own languages and history and reject 'White racism' in any of its manifestations. ${ }^{52}$ While the Marxist theory rejects the conception of 'justice being blind' and states that in a socialist state Lady Justice's eyes are wide open to the injustices of society. ${ }^{53}$ Decolonisation rejects the 'historical amnesia' induced by colonisers and places Africa at the centre of an envisaged alternative that is pluriversal and can lead to epistemic diversity and ultimately ensure access to justice to even those deemed to be 'below the law.' I do concede that I foresee the law continuing to aid and abet the English language as a means to further divide our already divided society. However, I hope that this article will start a conversation, the same way a group of students started a conversation in the 1960s and 70s about the inherent injustice of apartheid which gained momentum and ultimately saw one of the world's great racist regimes collapse, at least on paper.

50 Parmegiani (n 2) 92.

51 https://public.oed.com/updates/new-words-list-january-2018/\#new_words (accessed 1 November 2018).

52 Biko (n 17) 99.

53 (n 25). 